\title{
Release of covalently bound hydroxycinnamate, ferulic acid, from whole-grain
}

\author{
A. L. Turner ${ }^{1}$, P. R. Shewry ${ }^{1,2}$, A. Lovegrove $^{2}$ and J. P. E. Spencer ${ }^{1}$ \\ ${ }^{1}$ Food and Nutritional Sciences, University of Reading, Whiteknights Campus, Reading, RG6 6AR and ${ }^{2}$ Rothamsted \\ Research, Harpenden, AL5 $2 J Q$.
}

Plant phenolics are considered to have beneficial effects on human health, particularly in preventing cardiovascular disease risk through their actions on the vascular system. Whole-grain is a rich, sustainable source of phenolic acids, such as ferulic acid $(\text { FA })^{(1)}$ which accounts for $70-90 \%$ of the phenolic acid content of whole-grain ${ }^{(1,2)}$. However, most of the FA is covalently bound to arabinoxylans via ester-linkages. This bound FA has been reported to resist digestion in the upper gastrointestinal tract, limiting bioavailability ${ }^{(3)}$. Although feruloyl groups are released via interaction with the microbiota, $60 \%$ of residues remain insoluble ${ }^{(4)}$. We demonstrate that high release of FA can be achieved by using feruloyl esterase during bread making, potentially improving the bioavailability of FA in the upper gastrointestinal tract.

Whole-grain flours of three wheat cultivars, Hereward, Cadenza and Gallant were analysed for their soluble and bound FA content, using saponification to release the bound form. FA quantification was performed by HPLC with diode array detection. Utraflo L, a commercial enzyme preparation produced by fermentation of Humicola insolens, was used at different concentration levels and incubation times during flatbread making to assess the optimal conditions for release of bound FA. After the dough was mixed for 2.5 minutes using a hook mixer, it was incubated at $20^{\circ} \mathrm{C}$ for the required times and baked at $230{ }^{\circ} \mathrm{C}$ in a rotary oven for 8 minutes.

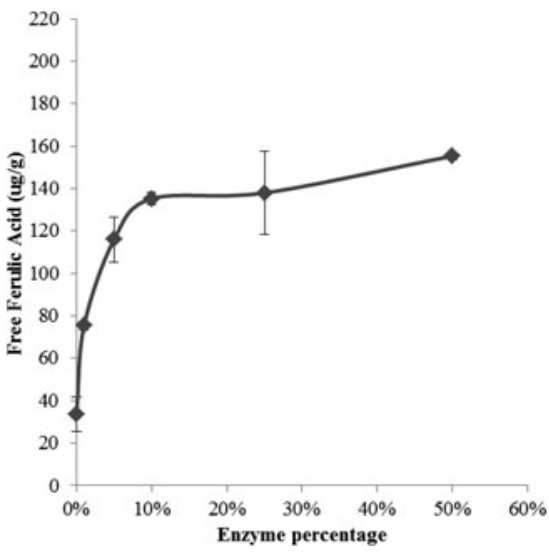

Fig. 1. Enzyme concentrations

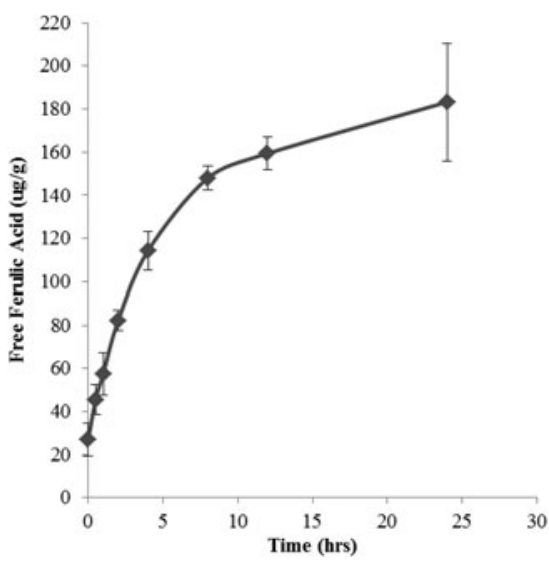

Fig. 2. Incubation time

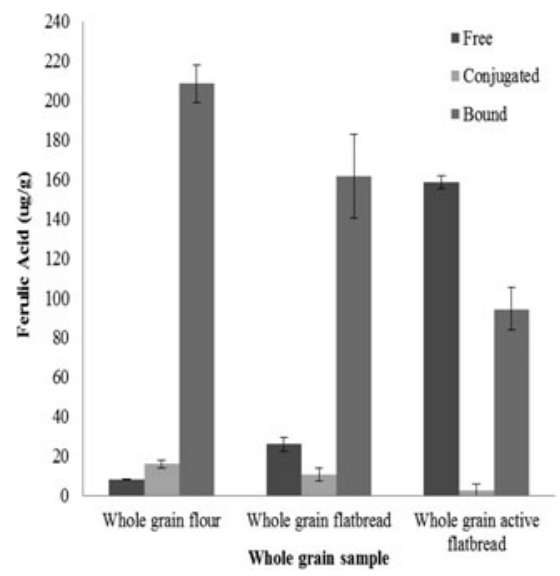

Fig. 3. Ferulic Acid in whole-grain

Hereward contained the highest concentration of insoluble FA $(244.84 \pm 2.78 \mathrm{ug} / \mathrm{g})$ compared to Cadenza $(214.09 \pm 3 \cdot 3 \mathrm{ug} / \mathrm{g})$ and Gallant $(155.8 \pm 3.12 \mathrm{ug} / \mathrm{g})$ and was therefore used for the study. Figs. 1 and 2 show the release of free FA from the insoluble state as a function of enzyme concentration and exposure time. The rate of release plateaued at 10\% Ultraflo L concentration (10:90 v/v Ultraflo L:water) and between 4 and 8 hours of incubation. During the mixing process, $23 \cdot 74 \mathrm{ug} / \mathrm{g}(\mathrm{NS}, n 6)$ of FA was released in the absence of the enzyme (Fig. 3). After $10 \%$ enzyme addition $150 \cdot 17 \mathrm{ug} / \mathrm{g}(P<0 \cdot 001, n 6)$ of free FA was liberated from the bound state (Fig. 3). This increase in free FA corresponded with a concurrent decrease in the amount of bound FA in the absence of enzyme, 208.35 ug/g to $177.07 \mathrm{ug} / \mathrm{g}(N S, n 6)$, compared to $208.35 \mathrm{ug} / \mathrm{g}$ to $94.45 \mathrm{ug} / \mathrm{g}(P<0.001, n 6)$ after enzyme addition (Fig. 3). The conjugated fraction also decreased from $25 \cdot 24 \mathrm{ug} / \mathrm{g}$ to $14.81 \mathrm{ug} / \mathrm{g}(N S n 6)$ during mixing and from $25 \cdot 24 \mathrm{ug} / \mathrm{g}$ to $3.46 \mathrm{ug} / \mathrm{g}(P<0 \cdot 05, n 6)$ with enzyme (Fig. 3).

These data indicate that incorporating dough with $10 \%$ Ultraflo $\mathrm{L}$ and a $4 \mathrm{~h}$ proving time are sufficient to release significant amounts of FA from the bound state without compromising dough quality. Our data indicate that use of a feruloyl esterase during bread making may significantly increase the amount of soluble, free FA in flour and breads. Using these data a FA-rich flatbread will be produced to assess the impact of free and bound FA intervention on blood pressure and vascular function in healthy individuals.

1. Li L, Shewry PR, Ward JL (2008) J. Agric. Food Chem 56, 9732-9739.

2. Adom KK, Sorrells ME, Liu RH (2005) J. Agric. Food Chem 53, 2297-2306.

3. Vitaglione P, Napolitano A, Fogliano V (2008) Trends Food Sci Tech 19, 451-63.

4. Kroon PA, Faulds CB, Ryden P (1997) J. Agric. Food Chem 45, 661-667. 